\title{
Framework Development of an Asset Manager Selection Based on Risk Management and Performance Improvement Competences
}

\author{
Damjan Maletič ${ }^{1, *(1)}$, Hana Pačaiová ${ }^{2, *(1)}$, Anna Nagyová ${ }^{2}$ (D) Boštjan Gomišček ${ }^{3}$ and Matjaž Maletič $1, *(1)$ \\ 1 Faculty of Organizational Sciences, University of Maribor, Kidričeva 55a, 4000 Kranj, Slovenia \\ 2 Faculty of Mechanical Engineering, Technical University of Košice, Letná 9, 04200 Košice, Slovakia; \\ anna.nagyova@tuke.sk \\ 3 Faculty of Business, University of Wollongong in Dubai, Knowledge Park, Block 15, P.O. Box, \\ Dubai 20183, United Arab Emirates; BostjanGomiscek@uowdubai.ac.ae \\ * Correspondence: damjan.maletic@um.si (D.M.); hana.pacaiova@tuke.sk (H.P.); matjaz.maletic@um.si (M.M.)
}

Citation: Maletič, D.; Pačaiová, H.; Nagyová, A.; Gomišček, B.; Maletič, M. Framework Development of an Asset Manager Selection Based on Risk Management and Performance Improvement Competences. Safety 2021, 7, 10. https://doi.org/ $10.3390 /$ safety7010010

Received: 13 December 2020

Accepted: 23 January 2021

Published: 2 February 2021

Publisher's Note: MDPI stays neutral with regard to jurisdictional claims in published maps and institutional affiliations.

Copyright: (c) 2021 by the authors. Licensee MDPI, Basel, Switzerland. This article is an open access article distributed under the terms and conditions of the Creative Commons Attribution (CC BY) license (https:// creativecommons.org/licenses/by/ $4.0 /)$.

\begin{abstract}
This research focuses on proposing a framework based on an analytic hierarchy process (AHP) for the selection/evaluation of managers in the field of asset management. A hierarchical structure is constructed, encompassing the set of competences under the role of risk management and performance improvement of the Institute of Asset Management's (IAM's) competences framework. It also describes the AHP implementation and illustrates the entire process with an example that uses IAM competences as model criteria. A sensitivity analysis is also carried out to confirm the robustness of the proposed methodology. As per the findings, the AHP was proven to be a usable and reliable method in selecting the most appropriate asset manager. Therefore, it can help organizations to plan and develop the competences they need to meet current and future needs. This study is among the few studies that focus on competence requirements for people working in asset management. As such, a novel approach for selecting managers in the field of asset management is proposed by this study.
\end{abstract}

Keywords: risk management; competences; asset management; analytic hierarchy process (AHP); decision making

\section{Introduction and Literature Review}

Good asset management is increasingly seen as normal practice in mature organizations around the world [1]. Asset management is an important part of any organization as it enables it to create value from its assets [2]. The goal of asset management is to enable organizations to have assets that meet their business needs and provide supporting services so that they can operate effectively [3]. Asset management encompasses a variety of disciplines, including engineering, finance, maintenance, risk management, human resources management, investment, sustainable efficiency, IT and more [4]. It starts with understanding the needs of the organization in line with its business objectives to deliver goods and services reliably, safely, on time and cost-effectively [5]. Asset management strategy begins with the organization's strategy and plan to achieve its objectives and then supports the delivery of the value associated with the organization's plan. However, ISO 55000 [6] does not provide information on the approach to asset management, but merely sets the direction for elements of an asset management system (AMS) focused on value creation and risk management.

Asset management translates organizational goals into asset-related decisions, plans and activities, using a risk-based approach [7-9]. The efficient management of existing and emerging risks is a topic that is well discussed within the asset management body of knowledge [10-15]. The impact (positive or negative) of uncertainties on an organization is 
referred to as risk, which leads to opportunities or threats [16]. Since every activity at every level involves risk, organizations of all sectors and sizes would prefer to deal with them in order to develop better strategies and make the right decisions [14]. Risk management is an integral part of ISO 55001 and should be considered in the overall risk management approach of the organization [2]. In recent years, a lot of attention has also been paid to asset performance evaluation and asset management [17]. Performance evaluation is also an important part of the AMS, as it is crucial to define appropriate financial and nonfinancial measures to evaluate performance against business objectives [6]. Managing asset performance under the prevailing dynamic business and industry scenarios is becoming increasingly critical and complex due to technological advancements [18].

Asset management requires a multidisciplinary approach $[9,19,20]$. Therefore, different competence requirements are needed in asset management. Of course, the mix of competences depends on the industry, context and environment in which the organization operates. Asset management requires competences that meet the requirements of knowledge, skills, experience, behavior, attitudes and attributes related to asset management [2]. The range of required knowledge includes an understanding of the technical areas of the business, the commercial needs of the business, the relevant suite of asset management techniques, the ability to bring together plans and projects and to present a balanced view of all aspects of an issue as a basis for developing business cases and decision making [3]. Nevertheless, ISO 55001 [2] includes a requirement for organizations to ensure that they understand the required skills of those involved in managing their assets and to review and update these on a regular basis. Accordingly, it is important to ensure that these individuals have the required skills and that they are aware of any competence gaps and have plans and processes in place to address these gaps. However, these are general requirements that provide little insight into how they can be met. There are several possible sources for asset management competences. The first is the competences framework developed by the Institute of Asset Management (Guidance [21] and Requirements [4]). The framework was originally developed to meet the requirements of PAS 55 [22] and has been updated since the issuance of ISO 55001 [2] to ensure consistency with the terminology in the aforementioned international standard. The framework is based on seven main asset management roles, namely, policy development, strategy development, asset management planning, asset management plan implementation, asset management capability development, risk management and performance improvement and asset knowledge management. A possible second source of asset management competences is the list of competences developed by the Asset Management Council [23] in Australia. It contains over 200 individual competences. However, this list of competences was developed primarily to support their individual certification scheme (e.g., Certified Practitioner in Asset Management-CPAM) rather than to assist organizations in identifying asset management competences. More recently, an asset management framework has been developed by the Canadian Network of Asset Managers (CNAM) to support communities in developing their asset management capacity [24]. Additionally, the Global Forum on Maintenance and Asset Management (GFMAM) has developed a competency specification framework [25]. These competency requirements have been created to provide the basis for ensuring the competence of persons responsible for auditing or assessing organizations according to ISO 55001. Considering only the maintenance perspective and engineered assets, the standard EN 15628 specifies requirements such as competences, essential knowledge and basic and target qualifications for maintenance personnel [26].

As more and more organizations take over asset management and the demand for asset managers increases, there is a growing interest in the personal skills of asset managers. Selecting the most qualified asset managers can be a daunting task due to the many aspects that should be considered, some of which are subjective. As it is important to select the most suitable person, decision support tools are needed to support and ensure a rigorous selection process. Multi-criteria decision-making techniques, namely, the analytic hierarchy process (AHP), have been extensively used to solve the problem of personnel 
selection based on the competence criteria hierarchies [27]. Personnel selection is one of the most important phases of the human resources management process [28]. The basic function of personnel selection is to identify, among the applicants who apply for specific positions in the company, those who have the necessary knowledge, skills and abilities to successfully meet the requirements of the position. Prior studies addressing competence requirements in asset management were merely focused on education (e.g., [29]) or competency model development (e.g., [30]). Despite the importance of these efforts, there is still a lack of studies addressing this topic. To the best of our knowledge, no previous studies have explicitly focused on developing a framework for the evaluation/selection of asset managers using decision-making techniques. To address this gap, this paper presents a novel approach for evaluating/selecting asset managers based on the Institute of Asset Management (IAM) competences framework. Accordingly, the purpose of this study is to contribute to the field of asset management by applying an analytic hierarchy process (AHP) for the evaluation/selection of personnel in the field of asset management. In this study, competences in risk management and performance improvement were used as an important topic in asset management.

The remainder of this paper is structured as follows. The introduction and literature review form the first section of the main body of the paper, followed by a brief overview of the AHP method in the second section. The third section presents the development and validation of the AHP-based framework for the selection of asset managers. It begins with a discussion of the steps involved in building an AHP-based framework, followed by the implementation of the proposed steps for asset manager selection. The final section of this paper outlines the main findings of this paper and some suggestions for future work.

\section{Methods}

This paper describes an application of the AHP to select the most appropriate asset manager. AHP is a tool for multi-criteria decision making [31]. The AHP is a method for solving complicated and unstructured problems that may have interactions and correlations between different goals and objectives. It was developed to solve complex problems at different hierarchical levels, where the goal is at the top, the intermediate levels being the criteria and sub-criteria and the lowest level being alternatives [31]. The AHP is a theory of measurement by pairwise comparisons and relies on expert judgements to derive priority scales. It takes into account the subjectivity of the decision-making process and allows decision makers to transform subjective assessment into objective measures. The comparisons are made using a scale of absolute judgements that represents how much more one element dominates another with respect to a particular attribute [32]. The AHP develops priorities under all criteria and sub-criteria within each level of the hierarchy. As such, AHP provides a rational framework for a needed decision by quantifying its criteria and alternative options and relating these elements to the overall goal [31]. The AHP method is widely used in different areas of the personnel selection process (e.g., [27]). However, in terms of asset management, the AHP is often used in the context of infrastructure assets (e.g., [33]) or water resources (e.g., [34]). In this study, an Excel template [35] was used to perform the AHP analysis. The sensitivity analysis was performed using the software Expert Choice.

The AHP application in this study was carried out by a seven-member team consisting of engineers and managers in the field of asset and maintenance management and/or safety and risk management (5) and academics (2) in the field of quality and asset management and/or asset/engineering risk management (see Table A1). A focus group discussion (FGD) was chosen as the appropriate method for data collection, which enabled the applicability of the AHP to asset management to be explored in depth with relevant, experienced professionals who were involved in the study. The study was conducted at one of the regular meetings of the Slovenian group of asset management professionals. 


\section{An AHP-Based Framework for Asset Manager Selection}

The AHP modeling process involves several stages, such as outlining the problem, structuring the decision hierarchy, making pairwise comparisons for each matrix, using the priorities obtained from the comparisons to weight the priorities at the level immediately below and continuing this process of weighing and adding until the final priorities of the alternatives are reached [31,32,36]. Thus, in previous AHP studies (e.g., [27,37]), several steps are identified for conducting the AHP according to the above guidelines. An AHP framework was developed on the basis of these guidelines. Figure 1 shows a flow chart with different steps for the implementation of the AHP study.
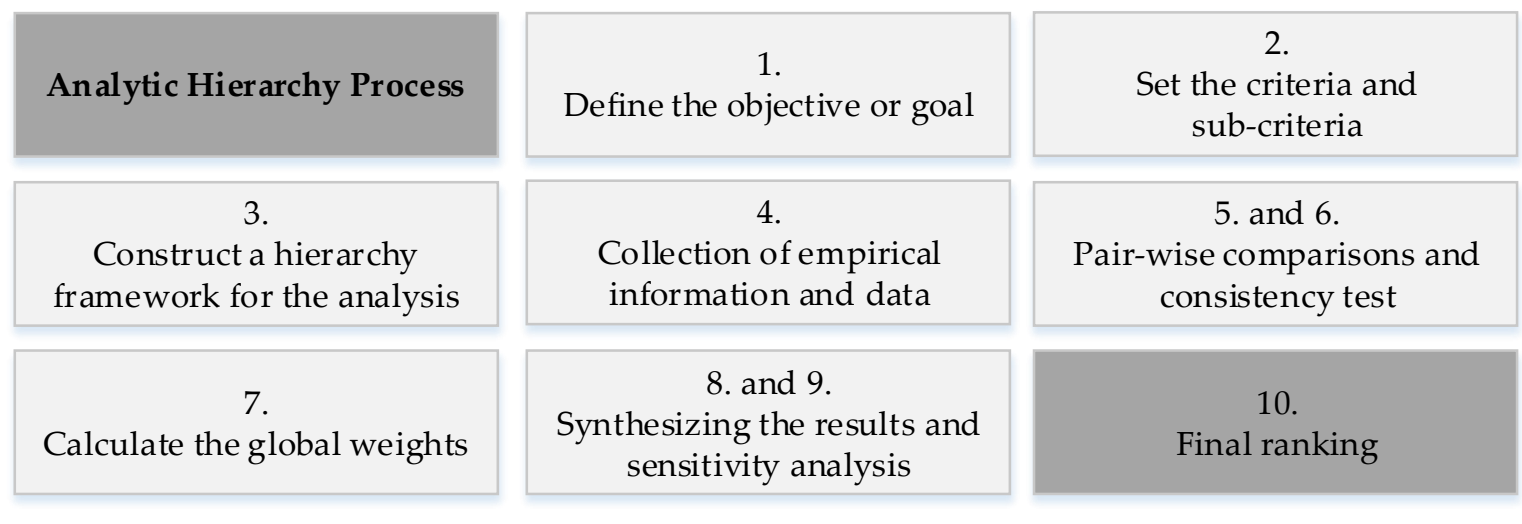

Figure 1. Steps in analytic hierarchy process (AHP) study.

Step 1: Define the objective or goal

As mentioned in the previous section, an important phase of the AHP is the definition of the hierarchy tree. Starting from the main goal (the first level of the hierarchy). The goal of this study is to evaluate and select the most appropriate asset manager. Specifically, this study addresses the possibility of using the AHP to select and prioritize the most appropriate factors for evaluating managers from the perspective of asset risk management and performance improvement. This study was conducted within a Slovenian group of asset management professionals. This group consists of several asset management specialists covering different aspects of asset management.

\section{Step 2: Identify criteria and sub-criteria}

Before the criteria and sub-criteria were defined, the area of asset management to be evaluated was identified and confirmed. The information collected from the literature, namely, the GFMAM's asset management landscape subjects [38], was assessed through brainstorming by seven experts consisting of academics and practitioners (see Table A1). As a result of the assessment, it was determined that risk and review is the most appropriate asset management subject for this AHP study. Within the scope of the study, the potential criteria and sub-criteria have been identified through literature review. According to the literature research, the IAM competences framework [4] was the one that came closest to the selected area. The IAM framework is a globally recognized competency requirements framework, allowing organizations to plan and develop the competences they need to meet current and future needs in the field of asset management. The role of risk management and performance improvement was chosen because it corresponds to the selected area of the GFMAM. The selected dimension (i.e., risk management and performance improvement) was subject to a two-stage breakdown of competence requirements into units and elements and a list of the underlying knowledge and understanding considered most relevant to the role. The units selected for this study are concerned with ensuring that organizations identify, understand and manage risk effectively and that performance is reviewed and improved over time. According to the IAM framework, risks include health and safety, security, environment, reputation, finance, etc. [4]. Units and elements were 
used as criteria and sub-criteria in this study. In this regard, the following criteria were considered: assess and manage risks (AMR), assure the quality of asset management (AM) processes (AQAM), monitor and review progress and performance (MRPP), review and audit compliance with legal, regulatory, ethical and social requirements (RACR) and learn from incidents (LI). The criteria and sub-criteria are presented in Table A2.

\section{Step 3: Construct a hierarchy framework for the analysis}

Once the objective of this study was defined, relevant criteria and sub-criteria were identified in steps 1 and 2. These criteria and sub-criteria were then structured in a hierarchy descending from the overall goal (see Figure 2). In this context, the study problem (i.e., evaluating and selecting the most appropriate asset manager) was decomposed into a series of hierarchies, with each level representing a smaller number of managed attributes. According to the decision team (i.e., a group of asset management professionals), five different sets of criteria should be used to represent the most critical issues in selecting the most appropriate asset manager. Following the hierarchy in Figure 2 and in conjunction with the standard AHP scale as defined by Saaty (see Table 1), data collection was conducted during the group sessions.

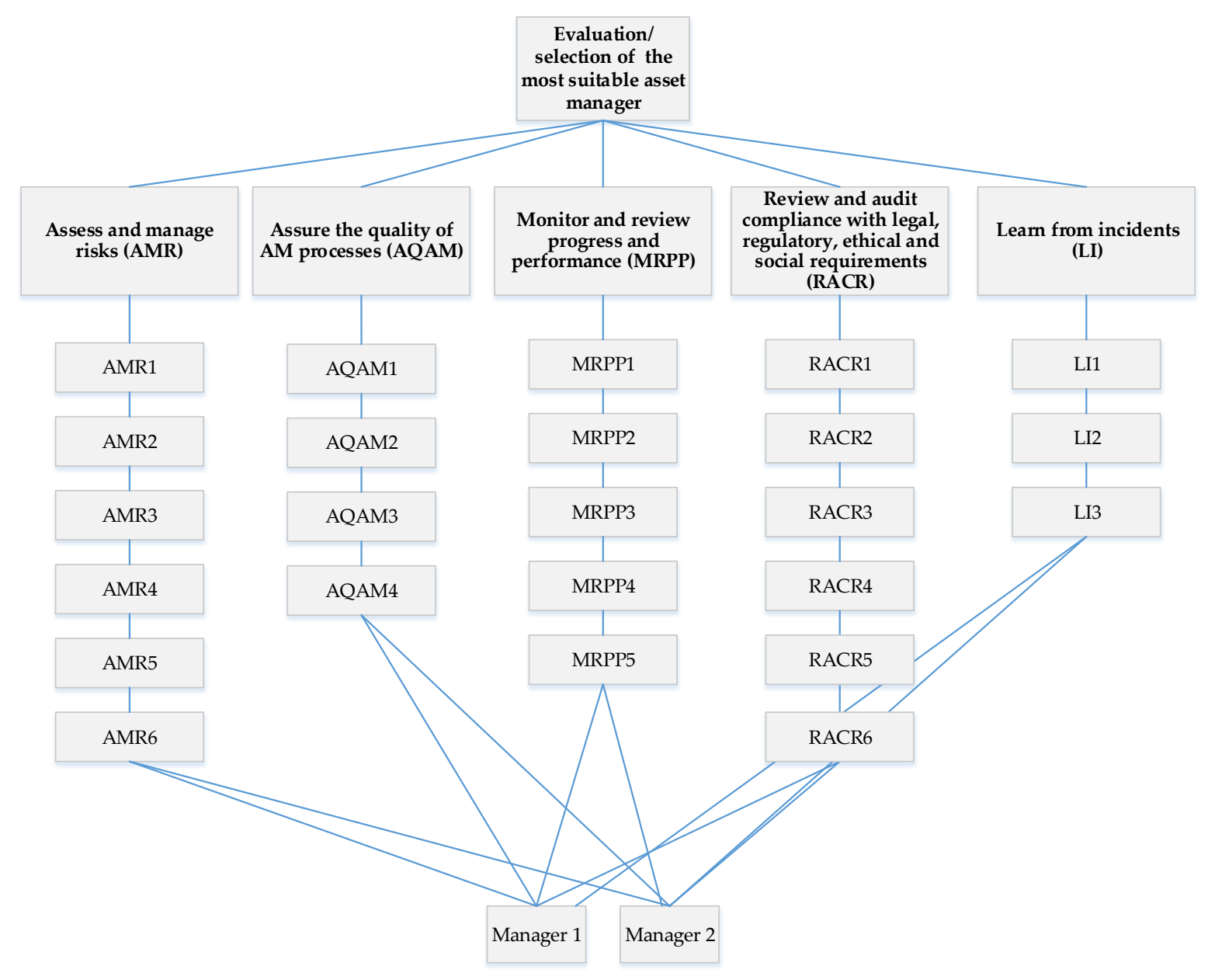

Figure 2. A hierarchy model for asset manager evaluation/selection.

Step 4: Collection of empirical information and data

This step involves the collection of empirical information and data through the combined judgments of the individual evaluators from the Slovenian group of asset management professionals. First, four experts in asset management were selected to evaluate the selected criteria. Second, an evaluator with sufficient knowledge, expertise and understanding of asset management was selected to guide the decision-making process. The IAM 
documents (Guidance [21] and Requirements [4]) were used to understand the role, units and elements of the competence framework. Both persons evaluated were asked to complete the self-evaluation of the selected sub-criteria of level 3. This was done prior to the interview with the evaluator, as the interview time was limited to one hour. For the purpose of self-evaluation, the following scale (see Table 2) was adopted from [39]. The self-evaluation was mainly used as support and input for conducting the interviews, especially to improve the decision-making process during the AHP study. Generally, essential elements of the data collection process were: (i) self-evaluation form for managers in accordance with the scale presented in Table 2; (ii) Excel template for the AHP using the Saaty scale (1-9) for criteria evaluation done by the above experts. Prior to actual data collection, the self-evaluation form was pilot tested within the AHP team (i.e., a group of professionals) to ensure that the criteria and corresponding scales were understandable. Empirical data on the criteria evaluation are provided in step 5 (see Table 3, which summarizes the pairwise comparison data).

Table 1. Scale of relative preference for pairwise comparison. Source: [31].

\begin{tabular}{cc}
\hline Scale & Judgement \\
\hline 1 & Equal importance \\
3 & Moderately preferred \\
5 & Strongly preferred \\
7 & Very strongly preferred \\
9 & Extremely preferred \\
$2,4,6,8$ & Intermediate values \\
\hline
\end{tabular}

Table 2. Competence levels.

\begin{tabular}{ccc}
\hline Level of Competence & & Description \\
\hline Proficiency & $\mathrm{P}$ & Able to manage, supervise and advise others \\
Experience & $\mathrm{E}$ & Capable of undertaking the competence independently \\
Knowledge & $\mathrm{K}$ & $\begin{array}{c}\text { Capable of contributing to the work of others but not of } \\
\text { undertaking the competence independently }\end{array}$ \\
Awareness & $\mathrm{A}$ & Is aware of the competence but has not practiced it \\
Not Applicable & NA & No experience, knowledge or training \\
\hline
\end{tabular}

Table 3. Pairwise comparison matrix of the main criteria with respect to the goal.

\begin{tabular}{ccccccc}
\hline & AMR & AQAM & MRPP & RACR & LI & Priorities \\
\hline $\begin{array}{c}\text { Assess and manage risks (AMR) } \\
\text { Assure the quality of AM processes }\end{array}$ & 1 & 3 & 2 & 2 & 3 & 0.362 \\
$\quad \begin{array}{c}\text { (AQAM) } \\
\begin{array}{c}\text { Monitor and review progress } \\
\text { and performance (MRPP) }\end{array}\end{array}$ & $1 / 2$ & 2 & 1 & 2 & 2 & 0.237 \\
$\begin{array}{c}\text { Review and audit compliance with } \\
\text { legal, regulatory, ethical and social } \\
\quad \text { requirements (RACR) }\end{array}$ & $1 / 2$ & 3 & $1 / 2$ & 1 & 1 & 0.175 \\
$\quad$ Learn from incidents (LI) & $1 / 3$ & 1 & $1 / 2$ & 1 & 1 & 0.124 \\
\hline Notes: $\mathrm{CI}=0.038 ; \mathrm{RI}=1.12 ; \mathrm{CR}=0.034 ; \lambda_{\max }=5.152$. & & & & $1 / 3$ &
\end{tabular}

Step 5: Perform pairwise comparisons for each level of criteria and sub-criteria

Once relevant empirical information and data were collected, the next step was to determine the relative importance between the criteria and sub-criteria (taking into account the self-assessment levels confirmed during the interview for the competence level of each person being evaluated, as mentioned above). The evaluator carefully compared the criteria at each hierarchical level by assigning relative scales in pairs in light of the goal of this study. A relational scale with real numbers from 1 to 9 was used for the rating (see Table 2). 
There are six pairwise comparison matrices in total: one for the criteria relating to the objective, which is presented here in Table 3, five for the sub-criteria, the first of which is for the sub-criteria under Assess and manage risks (see Table 4), the second under Assure the quality of asset management (AM) processes (see Table 5), the third under Monitor and review progress and performance (Table 6), the fourth under Review and audit compliance with legal, regulatory, ethical and social requirements (see Table 7) and finally under the sub-criterion Learn from incidents (Table 8). For illustrative purposes, the calculations for the priority vector are explained below. First, a normalized comparison matrix should be calculated by dividing each value in the pairwise comparison matrix by the sum of its column. For example, the value $\mathrm{X}_{11}(0.38)$ of the normalized pairwise matrix is obtained by dividing 1 (from Table 3 ) by 2.66 , the sum of the column items in Table 3 ( $1+$ $1 / 3+1 / 2+1 / 2+1 / 3)$. According to this calculation approach, the normalized pairwise matrix is generated. The priority vectors in Tables $3-8$ can be obtained by finding the row averages. For example, the priority value of AMR with respect to the goal is calculated by dividing the sum of the rows $(0.38+0.30+0.44+0.32+0.3819)$ by the number of criteria, i.e., 5 , in order to obtain the value of 0.362 (see Table 3 ).

Table 4. Pairwise comparison matrix for the sub-criteria with respect to AMR.

\begin{tabular}{cccccccc}
\hline Sub-Criteria & AMR1 & AMR2 & AMR3 & AMR4 & AMR5 & AMR6 & Priorities \\
\hline AMR1 & 1 & 2 & 3 & 2 & 1 & 1 & 0.230 \\
AMR2 & $1 / 2$ & 1 & 3 & 3 & 1 & 1 & 0.193 \\
AMR3 & $1 / 3$ & $1 / 3$ & 1 & 1 & $1 / 2$ & $1 / 3$ & 0.075 \\
AMR4 & $\frac{1}{2}$ & $1 / 3$ & 1 & 1 & $1 / 2$ & $1 / 3$ & 0.081 \\
AMR5 & 1 & 1 & 2 & 2 & 1 & $1 / 3$ & 0.158 \\
AMR6 & 1 & 1 & 3 & 3 & 3 & 1 & 0.263 \\
\hline
\end{tabular}

Notes: $\mathrm{CI}=0.039 ; \mathrm{RI}=1.24 ; \mathrm{CR}=0.031 ; \lambda_{\max }=6.195$.

Table 5. Pairwise comparison matrix for the sub-criteria with respect to AQAM.

\begin{tabular}{cccccc}
\hline Sub-Criteria & AQAM1 & AQAM2 & AQAM3 & AQAM4 & Priorities \\
\hline AQAM1 & 1 & 3 & 2 & 2 & 0.415 \\
AQAM2 & $1 / 3$ & 1 & $1 / 3$ & $1 / 2$ & 0.107 \\
AQAM3 & $1 / 2$ & 3 & 1 & 2 & 0.293 \\
AQAM4 & $1 / 2$ & 2 & $1 / 2$ & 1 & 0.185 \\
\hline Notes: $\mathrm{CI}=0.023 ; \mathrm{RI}=0.90 ; \mathrm{CR}=0.026 ; \lambda_{\max }=4.071$. &
\end{tabular}

Notes: $\mathrm{CI}=0.023 ; \mathrm{RI}=0.90 ; \mathrm{CR}=0.026 ; \lambda_{\max }=4.071$.

Table 6. Pairwise comparison matrix for the sub-criteria with respect to MRPP.

\begin{tabular}{ccccccc}
\hline & MRPP1 & MRPP2 & MRPP3 & MRPP4 & MRPP5 & Priorities \\
\hline MRPP1 & 1 & $1 / 3$ & 2 & 2 & 1 & 0.176 \\
MRPP2 & 3 & 1 & 3 & 5 & 2 & 0.400 \\
MRPP3 & $1 / 2$ & $1 / 3$ & 1 & 3 & $1 / 3$ & 0.116 \\
MRPP4 & $1 / 2$ & $1 / 5$ & $1 / 3$ & 1 & $1 / 5$ & 0.062 \\
MRPP5 & 1 & $1 / 2$ & 3 & 5 & 1 & 0.246 \\
\hline
\end{tabular}

Notes: $\mathrm{CI}=0.046 ; \mathrm{RI}=1.12 ; \mathrm{CR}=0.041 ; \lambda_{\max }=5.184$.

Table 7. Pairwise comparison matrix for the sub-criteria with respect to RACR.

\begin{tabular}{cccccccc}
\hline Sub-Criteria & RACR1 & RACR2 & RACR3 & RACR4 & RACR5 & RACR6 & Priorities \\
\hline RACR1 & 1 & 2 & 3 & 2 & 2 & 2 & 0.281 \\
RACR2 & $1 / 2$ & 1 & 3 & 2 & 2 & 2 & 0.224 \\
RACR3 & $1 / 3$ & $1 / 3$ & 1 & $1 / 3$ & 1 & $1 / 5$ & 0.066 \\
RACR4 & $1 / 2$ & $1 / 2$ & 3 & 1 & 2 & 2 & 0.178 \\
RACR5 & $1 / 2$ & $1 / 2$ & 1 & $1 / 2$ & 1 & $1 / 2$ & 0.091 \\
RACR6 & $1 / 2$ & $1 / 2$ & 5 & $1 / 2$ & 2 & 1 & 0.160 \\
\hline
\end{tabular}

Notes: $\mathrm{CI}=0.068 ; \mathrm{RI}=1.24 ; \mathrm{CR}=0.055 ; \lambda_{\max }=6.341$. 
Table 8. Pairwise comparison matrix for the sub-criteria with respect to LI.

\begin{tabular}{ccccc}
\hline Sub-Criteria & LI1 & LI2 & LI3 & Priorities \\
\hline LI1 & 1 & 2 & 3 & 0.493 \\
LI2 & $1 / 2$ & 1 & 2 & 0.311 \\
LI3 & $1 / 2$ & $1 / 2$ & 1 & 0.196 \\
\hline Notes: $\mathrm{CI}=0.027 ; \mathrm{RI}=0.58 \cdot \mathrm{CR}=0.046 \cdot \lambda_{\max }=3.054$ &
\end{tabular}

\section{Step 6: Perform the consistency test}

In this step, a consistency test was performed. A measure of inconsistency is useful for identifying possible errors in the expression of judgments as well as actual inconsistencies in the judgments themselves [31]. The AHP provides a method called the consistency ratio (CR) to assess whether a criterion can be used for decision making. In the AHP, pairwise comparisons in an assessment matrix are considered consistent if the $\mathrm{CR}$ is less than $10 \%$ [31]. Thus, the CR was calculated according to the following equation: $\mathrm{CR}=\mathrm{CI} / \mathrm{RI}$. The consistency index $(\mathrm{CI})$ was calculated according to the following equation: $\mathrm{CI}=\lambda_{\max }$ $-n / n-1$, where " $n$ " is the number of criteria or sub-criteria of each level and $\lambda_{\max }$ is the largest eigenvector. The values for the eigenvectors were obtained using an Excel template [35]. The following table (see Table 9) shows the values of the random index (RI).

Table 9. Consistency ratio random number index. Source: [31].

\begin{tabular}{ccccccccccc}
\hline Size of Matrix & $\mathbf{1}$ & $\mathbf{2}$ & $\mathbf{3}$ & $\mathbf{4}$ & $\mathbf{5}$ & $\mathbf{6}$ & $\mathbf{7}$ & $\mathbf{8}$ & $\mathbf{9}$ & $\mathbf{1 0}$ \\
\hline Random index $(\mathrm{RI})$ & 0 & 0 & 0.58 & 0.90 & 1.12 & 1.24 & 1.32 & 1.41 & 1.45 & 1.51 \\
\hline
\end{tabular}

All values for the CI, RI, CR and $\lambda_{\max }$ are shown in Tables 3-8 (see notes). As can be evident from the results, all values obtained for the CR were below $10 \%$.

Step 7: Calculate the global weights of each criterion and sub-criterion

In this step, the priority weights are divided into "local weights"—-the priority weight in relation to the previous hierarchical level—and "global weights"—-the priority weight in relation to the highest hierarchical level — the goal or objective. The value of a local weight (LW) represents the priority weight of each category. The sum of all values in each level of the model must equal 1.00. Global weight (GW) is calculated by multiplying the LW of each sub-criterion by the local weight of the corresponding main criterion. For example, the GW for AMR1 (0.083) is calculated by multiplying the LW of AMR1 (0.230) by the LW of the main AMR criterion (0.362). A calculation of the local and global weights is presented in Table 10. 
Table 10. The local and global weights.

\begin{tabular}{|c|c|c|c|c|c|}
\hline \multirow{2}{*}{$\begin{array}{c}\text { Hierarchy } \\
\text { Level }\end{array}$} & \multirow{2}{*}{ Criteria } & \multicolumn{2}{|c|}{ Local Weights } & \multicolumn{2}{|c|}{ Global Weights } \\
\hline & & Weights & Ranking & Weights & Ranking \\
\hline \multirow[t]{6}{*}{ Level 2} & With respect to the goal & & & & \\
\hline & Assess and manage risks (AMR) & 0.362 & 1 & 0.362 & 1 \\
\hline & $\begin{array}{l}\text { Assure the quality of AM } \\
\text { processes (AQAM) }\end{array}$ & 0.102 & 5 & 0.102 & 5 \\
\hline & $\begin{array}{l}\text { Monitor and review progress } \\
\text { and performance (MRPP) }\end{array}$ & 0.237 & 2 & 0.237 & 2 \\
\hline & $\begin{array}{l}\text { Review and audit compliance } \\
\text { with legal, regulatory, ethical } \\
\text { and social requirements (RACR) }\end{array}$ & 0.175 & 3 & 0.175 & 3 \\
\hline & Learn from incidents (LI) & 0.124 & 4 & 0.124 & 4 \\
\hline \multirow[t]{29}{*}{ Level 3} & With respect to $A M R$ & & & & \\
\hline & AMR1 & 0.230 & 2 & 0.083 & 3 \\
\hline & AMR2 & 0.193 & 3 & 0.070 & 4 \\
\hline & AMR3 & 0.075 & 6 & 0.027 & 17 \\
\hline & AMR4 & 0.081 & 5 & 0.029 & 15 \\
\hline & AMR5 & 0.158 & 4 & 0.057 & 7 \\
\hline & AMR6 & 0.263 & 1 & 0.095 & 1 \\
\hline & With respect to $A Q A M$ & & & & \\
\hline & AQAM1 & 0.415 & 1 & 0.042 & 9 \\
\hline & AQAM2 & 0.107 & 4 & 0.011 & 24 \\
\hline & AQAM3 & 0.293 & 2 & 0.030 & 14 \\
\hline & AQAM4 & 0.185 & 3 & 0.019 & 20 \\
\hline & With respect to $M R P P$ & & & & \\
\hline & MRPP1 & 0.176 & 3 & 0.042 & 9 \\
\hline & MRPP2 & 0.400 & 1 & 0.095 & 1 \\
\hline & MRPP3 & 0.116 & 4 & 0.027 & 17 \\
\hline & MRPP4 & 0.062 & 5 & 0.015 & 22 \\
\hline & MRPP5 & 0.246 & 2 & 0.058 & 6 \\
\hline & With respect to $R A C R$ & & & & \\
\hline & RACR1 & 0.281 & 1 & 0.049 & 8 \\
\hline & RACR2 & 0.224 & 2 & 0.039 & 11 \\
\hline & RACR3 & 0.066 & 6 & 0.012 & 23 \\
\hline & RACR4 & 0.178 & 3 & 0.031 & 13 \\
\hline & RACR5 & 0.091 & 5 & 0.016 & 21 \\
\hline & RACR6 & 0.160 & 4 & 0.028 & 16 \\
\hline & With respect to $L I$ & & & & \\
\hline & LI1 & 0.493 & 1 & 0.061 & 5 \\
\hline & LI2 & 0.311 & 2 & 0.039 & 11 \\
\hline & LI3 & 0.196 & 3 & 0.024 & 19 \\
\hline
\end{tabular}

Step 8: Synthesizing the results

In order to obtain the final results, the results of managers 1 and 2 were multiplied by the global weighting of each decision criterion (see Table 11). The mechanism for calculating the final priority consists of multiplying the global priority of each sub-criterion by the alternative priority. The priorities for alternatives (managers 1 and 2) are presented in Table A3. 
Table 11. The summarized results.

\begin{tabular}{|c|c|c|}
\hline Sub-Criteria & Manager 1 & Manager 2 \\
\hline \multicolumn{3}{|c|}{ With respect to $A M R$} \\
\hline AMR1 & 0.069 & 0.014 \\
\hline AMR2 & 0.052 & 0.017 \\
\hline AMR3 & 0.005 & 0.023 \\
\hline AMR4 & 0.005 & 0.024 \\
\hline AMR5 & 0.014 & 0.043 \\
\hline AMR6 & 0.079 & 0.016 \\
\hline \multicolumn{3}{|c|}{ With respect to $A Q A M$} \\
\hline AQAM1 & 0.032 & 0.011 \\
\hline AQAM2 & 0.008 & 0.003 \\
\hline AQAM3 & 0.007 & 0.022 \\
\hline AQAM4 & 0.003 & 0.016 \\
\hline \multicolumn{3}{|c|}{ With respect to MRPP } \\
\hline MRPP1 & 0.028 & 0.014 \\
\hline MRPP2 & 0.063 & 0.032 \\
\hline MRPP3 & 0.005 & 0.023 \\
\hline MRPP4 & 0.002 & 0.012 \\
\hline MRPP5 & 0.044 & 0.015 \\
\hline \multicolumn{3}{|c|}{ With respect to $R A C R$} \\
\hline RACR1 & 0.033 & 0.016 \\
\hline RACR2 & 0.010 & 0.029 \\
\hline RACR3 & 0.002 & 0.010 \\
\hline RACR4 & 0.026 & 0.005 \\
\hline RACR5 & 0.003 & 0.013 \\
\hline RACR6 & 0.021 & 0.007 \\
\hline \multicolumn{3}{|l|}{ With respect to $L I$} \\
\hline LI1 & 0.015 & 0.046 \\
\hline LI2 & 0.013 & 0.026 \\
\hline LI3 & 0.020 & 0.004 \\
\hline$\Sigma$ & 0.560 & 0.440 \\
\hline
\end{tabular}

Table 11 calculates the global priorities for each of the managers. The highest value (0.560) corresponds to manager 1 , while 0.440 corresponds to manager 2 .

Step 9: Sensitivity analysis

In this step, a sensitivity analysis is performed to show how the change in various parameters of the model affects the final results. The dynamic sensitivity of Expert Choice was performed to analyze the change in the result caused by a change in each of the main criteria. Dynamic sensitivity analysis is used to dynamically change the priorities of the criteria to determine how these changes affect the priorities of the alternative choices. First, the criterion Assess and manage risks (AMR) was increased by about $25 \%$ (from $36.2 \%$ to $45.5 \%$ ). The results are shown in Figure 3. This figure consists of two parts. The results shown on the left side of Figure 3 are criteria and their corresponding weighting, while the right side of the figure illustrates the ranking of the alternative (managers 1 and 2), expressed by the importance (in percentage). The results of the sensitivity analysis showed that a change (an increase of 25 percent) in the first criterion has no significant effect on the final ranking. 


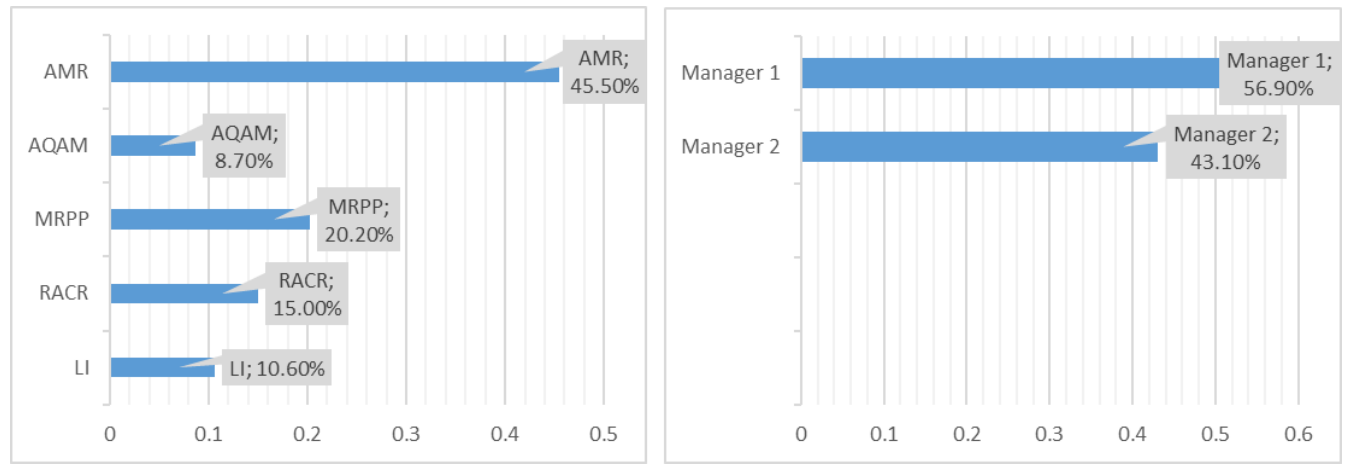

Figure 3. Scenario 1 (own processing).

Secondly, the criterion Assure the quality of AM processes (AQAM) was increased by about 25 percent (from $10.2 \%$ to $12.7 \%$ ) (see Figure 4). The final ranking remained unchanged.

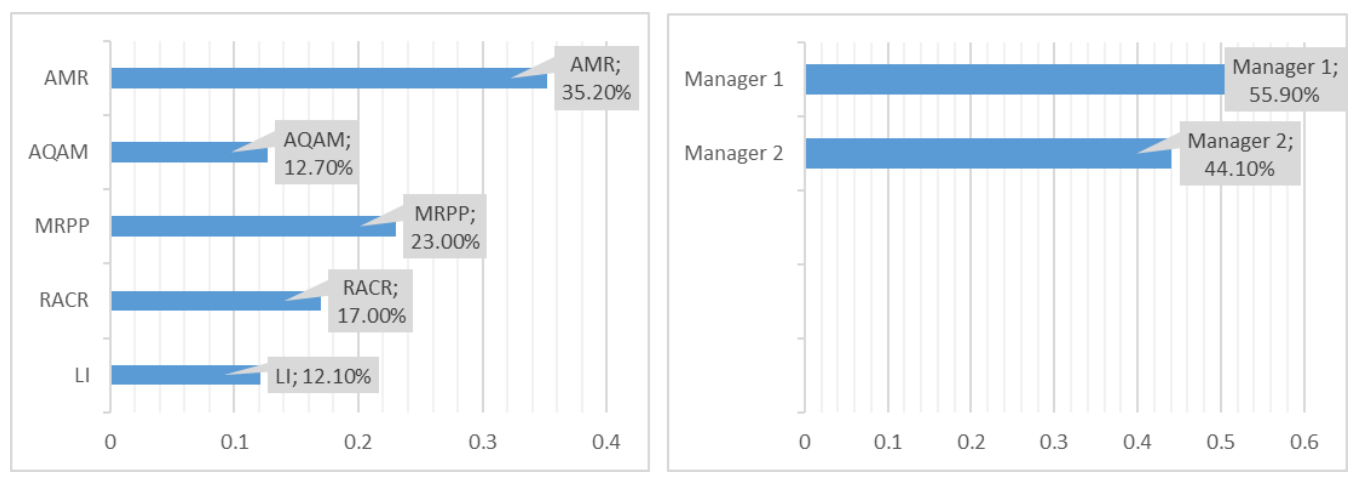

Figure 4. Scenario 2 (own processing).

Thirdly, the criterion Monitor and review progress and performance (MRPP) was increased by about 25 percent (from $23.7 \%$ to $29.6 \%$ ) (see Figure 5). The final ranking remained unchanged.

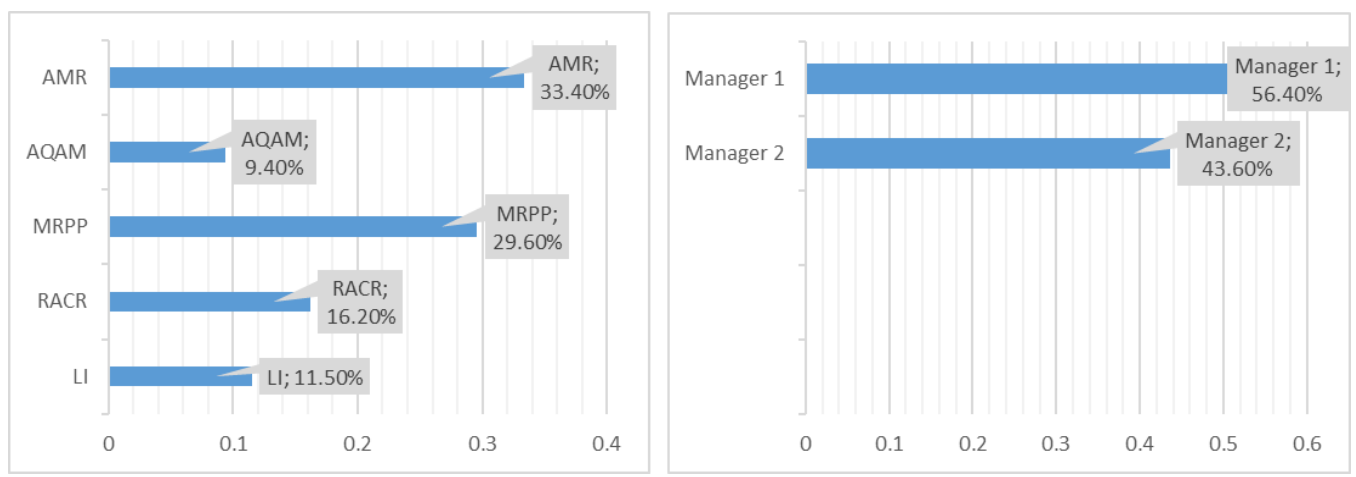

Figure 5. Scenario 3 (own processing).

Fourthly, the criterion Review and audit compliance with legal, regulatory, ethical and social requirements (RACR) was increased by about 25 percent (from $17.5 \%$ to $21.7 \%$ ) (see Figure 6). The final ranking remained unchanged. 


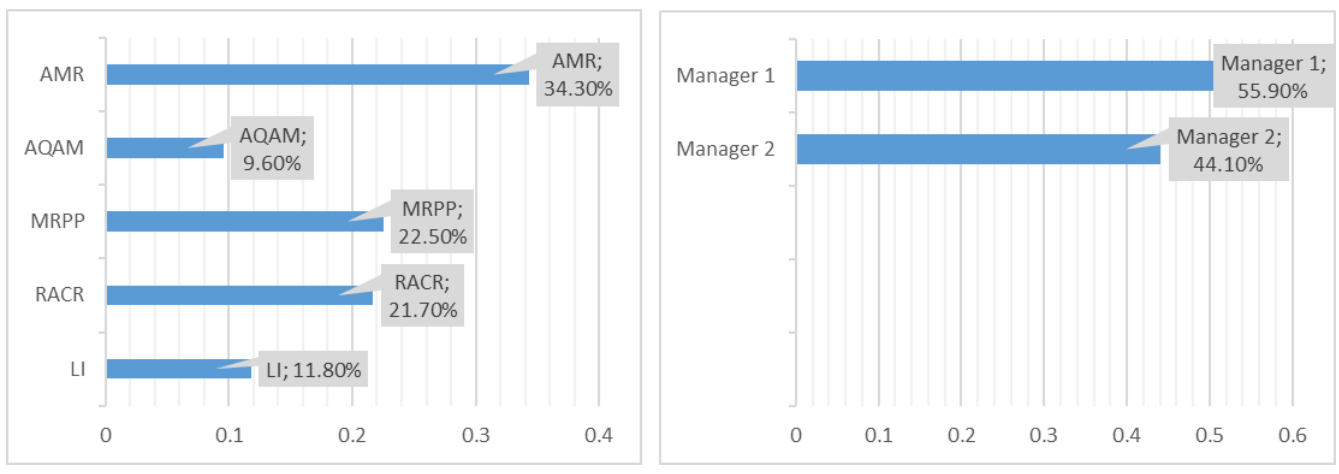

Figure 6. Scenario 4 (own processing).

Finally, the last criterion Learn from incidents (LI) was also increased by 25 percent (from $12.4 \%$ to $15.7 \%$ ). The final ranking (see Figure 7 ) remains unchanged as in the previous scenarios.

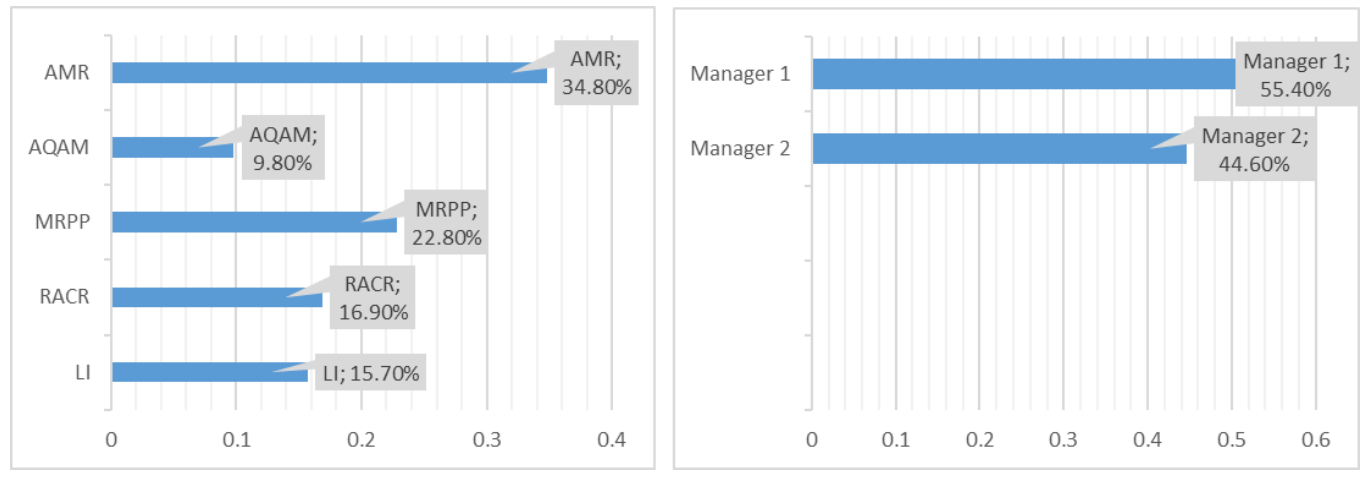

Figure 7. Scenario 5 (own processing).

In addition to the increase, we also reduced all criteria by 25 percent. The final ranking remained stable in all cases. As a result of the sensitivity analyses, we found that the outcome of our analysis is very robust and the final ranking of the alternatives can be confirmed.

Step 10: Final ranking of the proposed alternatives

Considering the results of step 9 and the results of the sensitivity analysis, the final solution of the AHP method can be determined. According to the results, manager $1(0.560)$ achieved a better result than manager 2 (0.440).

\section{Discussion and Implications}

As the success and survival of a business depends on the ability of the organization to successfully manage its assets [20], the analysis of factors that may have an impact on performance outcomes becomes increasingly important. Organizations can adopt and implement a wide range of asset management activities, including those related to asset condition maintenance, asset acquisition, asset life cycle, asset performance, risk management, asset criticality, asset safety and security, return on investment, financial performance, asset value, etc. $[9,40]$. With the development of a proactive organizational culture in engineering asset management, employees are becoming increasingly important as assets [41]. Moreover, employees are an important stakeholder group that has not received sufficient attention in the asset management literature. By linking risk management and performance improvement practices with the competence requirements for people working in asset management, this paper proposes an AHP methodology for evaluating/selecting the most appropriate asset manager. Using the proposed framework, the most suitable manager can be selected 
based on various asset management themes and the corresponding asset management competence framework. In this regard, this study shows that the proposed AHP methodology is applicable as an evaluation technique, and the proposed framework certainly facilitates the decision maker's task of selecting the most suitable asset manager. Accordingly, it is argued that an important aspect is the quality of the assessments made by decision makers. By using our AHP framework, decision makers can expect a broader and more complex understanding of the competence requirements for risk management and performance improvement in asset management. Several studies have already analyzed the knowledge and skill requirements for various disciplines, such as lean management [42]. However, this study characterizes the competence framework for asset management professionals, especially by emphasizing risk management and performance-related roles and activities. Based on the literature review, we argue that the specifics of asset management are not explored in detail. To this end, this study provides a comprehensive conceptualization and prioritization of the competency requirements for risk management and performance improvement that are relevant in the field of asset management.

\section{Implications}

The findings of this study have theoretical and practical implications in areas that have not been adequately explored in previous studies. In this study, the AHP was used to determine the importance of various factors in the selection of asset managers. While previous AHP studies on asset risk management have been limited to, among other things, risk-based asset management, which focuses on prioritizing the most critical assets by assessing their default risk (e.g., [43]), this study applies the AHP to the asset manager selection process, focusing on competence requirements. The results of this study support the established notion in the literature indicating the significant importance of risk management within asset management $[7,10]$. In support of previous studies that have examined the human factor in relation to expertise, decision making and competence, an important theoretical implication is also the extension of the previously mentioned findings to the asset management [44], safety (e.g., [45,46]) and risk management literature [47].

Furthermore, the study showed that not all factors of asset risk management and performance improvement are considered equally important. The results of this study show the highest priority for the assessment and management of risks (AMR) (0.362) and monitoring and reviewing the progress and performance (MRPP) (0.237). The emphasis on assessing and managing of risks and the orientation towards performance evaluation point to the need to recognize the value of an end-to-end systematic approach to AMSs [48]. In this respect, this study contributes to the operationalization of asset management models or frameworks. This finding supports previous studies that have demonstrated the relevance of risk management in the context of asset management.

In addition, the AHP provides asset managers with effective tools to identify risk management and performance improvement priorities within their organizations and to plan for staff training and development. Accordingly, organizations should provide sufficient training to employees to improve their skills and knowledge. In short, our findings imply that organizations should take initiatives to improve the areas of risk management and performance improvement of asset management. Additionally, organizations should focus on employees' competences as a core driver for developing a comprehensive AMS.

\section{Conclusions}

The gap in the literature and future research suggestions made by previous studies in the field of asset management motivated the authors of this study to investigate the areas of risk management and performance improvement that are particularly framed within asset management discipline. Specifically, this paper demonstrates the application of the AHP method in the process of selecting asset managers, mainly from the perspective of risk management and performance improvement competences. One of the challenges in applying this method is to determine the second-level attributes (i.e., decision criteria) 
and their importance (i.e., weight). To this end, the body of knowledge on asset management was considered to identify the most relevant criteria. In addition, an expert panel was established to evaluate the main criteria. In terms of the importance of the main criteria, our study shows that assessing and managing risk is the most important criterion among the five criteria in the proposed competence framework, followed by monitoring and reviewing progress and performance as the second most important criterion. Although a solid base of experience and previous scientific research has been used for this purpose, it should be pointed out that the AHP methodology is based on a subjective approach. While we acknowledge that the AHP looks at a pair of criteria and determines their weights based on preferences and considers them constant across alternatives, which could be a potential limitation, our case study results reinforce the importance and applicability of this method in the asset manager selection process, where comparison is potentially subjective and difficult to quantify. Although the AHP has been extensively applied in a variety of settings, this study differs from the literature in its application to the emerging discipline of asset management by prioritizing the decision attributes of risk management and performance improvement and by providing a competences framework for the asset manager selection process.

\section{Limitations and Future Scope}

The criteria and sub-criteria considered in the study were taken from a review of the relevant literature (see Section 3). Although the extant literature was considered, it is possible that a more complete hierarchy of criteria and sub-criteria may be established for future studies. Another limitation relates to the AHP methodology, as the rating scale used in the methodology is conceptual. Therefore, pairwise comparisons of different criteria and sub-criteria may lead to a potential bias. It should also be noted that some of the criteria and sub-criteria used in the model may be interrelated, such as the assessment and management of risks, monitoring and review of progress and performance, etc. To overcome this limitation, future studies could consider an analytic network process (ANP). Future studies should be extended to different organizational contexts and different operating conditions to improve the generalizability of the results. In particular, to further validate the proposed framework, the authors suggest applying it in different organizational settings using different asset management themes. In addition, future studies could consider our framework and the AHP approach to measure and compare the competency levels of different business units/teams.

Author Contributions: Conceptualization, D.M., H.P., A.N., B.G. and M.M.; formal analysis, D.M. and M.M.; writing—original draft preparation, D.M., writing—review and editing, D.M., H.P., A.N. and M.M.; supervision D.M., H.P., B.G. and M.M. All authors have read and agreed to the published version of the manuscript.

Funding: This research received no external funding.

Institutional Review Board Statement: Not applicable.

Informed Consent Statement: Not applicable.

Acknowledgments: This research was supported by the Slovenian Research Agency; Program No. P5-0018-Decision Support Systems in Digital Business, and also by the projects: APVV No. 19-0367 Framework of the Integrated Process Safety Management Approach for the Intelligent Enterprise, and KEGA No. 015TUKE-4/2019 Audit management using software application according to standard ISO 9001:2015.

Conflicts of Interest: The authors declare no conflict of interest. The funders had no role in the design of the study; in the collection, analyses, or interpretation of data; in the writing of the manuscript, or in the decision to publish the results. 


\section{Appendix A}

Table A1. Demographic data of evaluators.

\begin{tabular}{|c|c|c|c|c|c|}
\hline Gender & $\begin{array}{l}\text { Age } \\
\text { Group }\end{array}$ & $\begin{array}{l}\text { Education } \\
\text { (Degree) }\end{array}$ & Occupation & $\begin{array}{l}\text { Main Field } \\
\text { of Expertise }\end{array}$ & $\begin{array}{l}\text { Experience } \\
\text { (Years) }\end{array}$ \\
\hline Male & $>50$ & PhD degree & Private sector & $\begin{array}{c}\text { Asset } \\
\text { and maintenance } \\
\text { management, safety } \\
\text { and risk } \\
\text { management }\end{array}$ & $>30$ \\
\hline Male & $>50$ & $\begin{array}{l}\text { Bachelor } \\
\text { degree }\end{array}$ & Private sector & $\begin{array}{c}\text { Asset } \\
\text { and maintenance } \\
\text { management }\end{array}$ & $>20$ \\
\hline Male & $>50$ & $\begin{array}{l}\text { Bachelor } \\
\text { degree }\end{array}$ & Public sector & $\begin{array}{c}\text { Asset } \\
\text { and maintenance } \\
\text { management }\end{array}$ & $>30$ \\
\hline Male & $>50$ & $\begin{array}{l}\text { Master } \\
\text { degree }\end{array}$ & Private sector & $\begin{array}{c}\text { Asset } \\
\text { and maintenance } \\
\text { management }\end{array}$ & $>20$ \\
\hline Male & $>50$ & $\begin{array}{l}\text { Master } \\
\text { degree }\end{array}$ & Private sector & $\begin{array}{l}\text { Maintenance } \\
\text { management }\end{array}$ & $>20$ \\
\hline Male & $41-50$ & PhD degree & $\begin{array}{l}\text { University/Public } \\
\text { sector }\end{array}$ & $\begin{array}{l}\text { Asset management, } \\
\text { asset/Engineering } \\
\text { risk management }\end{array}$ & $10-15$ \\
\hline Male & $41-50$ & PhD degree & $\begin{array}{l}\text { University / Public } \\
\text { sector }\end{array}$ & $\begin{array}{l}\text { Quality and asset } \\
\text { management }\end{array}$ & $10-15$ \\
\hline
\end{tabular}

Table A2. List of criteria and sub-criteria for the risk management and performance improvement role (source: [4]).

\begin{tabular}{|c|c|}
\hline Unit & Assess and Manage Risks (AMR) \\
\hline 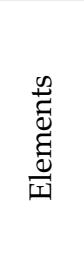 & $\begin{array}{l}\text { AMR1: Define and manage risk management processes and procedures } \\
\text { AMR2: Identify and assess risks arising from AM activities } \\
\text { AMR3: Specify measures and methods for controlling identified risks } \\
\text { AMR4: Identify improvements needed in working practices and procedures } \\
\text { AMR5: Monitor the progress and impact of improvement actions } \\
\text { AMR6: Integrate AM-related risk management with organizational risk } \\
\text { management systems }\end{array}$ \\
\hline Unit & Assure the quality of AM processes (AQAM) \\
\hline 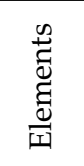 & $\begin{array}{l}\text { AQAM1: Assure the quality of AM products or processes } \\
\text { AQAM2: Identify the reasons for quality assurance problems } \\
\text { AQAM3: Plan and implement improvements to the quality of AM processes } \\
\text { AQAM4: Evaluate the effectiveness of process improvements }\end{array}$ \\
\hline Unit & Monitor and review progress and performance (MRPP) \\
\hline 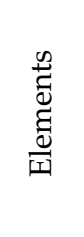 & $\begin{array}{l}\text { MRP1: Assess asset condition and performance against AM strategy and objectives } \\
\text { MRP2: Assess the performance of AM activities against AM strategy and objectives } \\
\text { MRP3: Identify and implement corrective actions } \\
\text { MRP4: Analyze the progress, impact and effectiveness of corrective actions } \\
\text { MRP5: Identify lessons learned and adjust AM strategy, policies } \\
\text { and procedures accordingly }\end{array}$ \\
\hline Unit & $\begin{array}{l}\text { Review and audit compliance with legal, regulatory, ethical, and social } \\
\text { requirements (RACR) }\end{array}$ \\
\hline$\underset{\frac{\infty}{0}}{\stackrel{\infty}{\rightleftarrows}}$ & $\begin{array}{l}\text { RAR1: Identify and monitor relevant legal, regulatory, ethical and social requirements } \\
\text { RAR2: Develop effective policies and procedures to make sure requirements are met } \\
\text { RAR3: Assess how policies and procedures are put into practice and provide support }\end{array}$ \\
\hline
\end{tabular}


Table A2. Cont.

\begin{tabular}{|c|c|}
\hline Unit & $\begin{array}{l}\text { Review and audit compliance with legal, regulatory, ethical, and social } \\
\text { requirements (RACR) }\end{array}$ \\
\hline 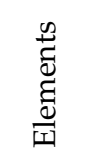 & $\begin{array}{l}\text { RAR4: Audit compliance with relevant legislation and standards } \\
\text { RAR5: Identify and correct any failures to meet requirements } \\
\text { RAR6: Identify reasons why requirements are not met and adjust policies } \\
\text { and procedures accordingly }\end{array}$ \\
\hline Unit & Learn from incidents (LI) \\
\hline 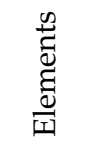 & $\begin{array}{l}\text { LI1: Investigate root cause of asset or system failures or incidents } \\
\text { LI2: Influence investigation of incidents } \\
\text { LI3: Make effective use of "lessons learned" information from incidents }\end{array}$ \\
\hline
\end{tabular}

Table A3. The priorities for alternatives.

\begin{tabular}{|c|c|c|}
\hline Sub-Criteria & Manager 1 & Manager 2 \\
\hline \multicolumn{3}{|c|}{$\begin{array}{l}\text { Assess and manage risks } \\
\text { (AMR) }\end{array}$} \\
\hline AMR1 & 0.83 & 0.17 \\
\hline AMR2 & 0.75 & 0.25 \\
\hline AMR3 & 0.17 & 0.83 \\
\hline AMR4 & 0.17 & 0.83 \\
\hline AMR5 & 0.25 & 0.75 \\
\hline AMR6 & 0.83 & 0.17 \\
\hline \multicolumn{3}{|c|}{$\begin{array}{l}\text { Assure the quality of AM } \\
\text { processes (AQAM) }\end{array}$} \\
\hline AQAM1 & 0.75 & 0.25 \\
\hline AQAM2 & 0.75 & 0.25 \\
\hline AQAM3 & 0.25 & 0.75 \\
\hline AQAM4 & 0.17 & 0.83 \\
\hline \multicolumn{3}{|c|}{$\begin{array}{l}\text { Monitor and review progress } \\
\text { and performance (MRPP) }\end{array}$} \\
\hline MRPP1 & 0.67 & 0.33 \\
\hline MRPP2 & 0.67 & 0.33 \\
\hline MRPP3 & 0.17 & 0.83 \\
\hline MRPP4 & 0.17 & 0.83 \\
\hline MRPP5 & 0.75 & 0.25 \\
\hline \multicolumn{3}{|c|}{$\begin{array}{l}\text { Review and audit compliance } \\
\text { with legal, regulatory, ethical } \\
\text { and social requirements } \\
\text { (RACR) }\end{array}$} \\
\hline RACR1 & 0.67 & 0.33 \\
\hline RACR2 & 0.25 & 0.75 \\
\hline RACR3 & 0.17 & 0.83 \\
\hline RACR4 & 0.83 & 0.17 \\
\hline RACR5 & 0.17 & 0.83 \\
\hline RACR6 & 0.75 & 0.25 \\
\hline \multicolumn{3}{|c|}{ Learn from incidents (LI) } \\
\hline LI1 & 0.25 & 0.75 \\
\hline LI2 & 0.33 & 0.67 \\
\hline LI3 & 0.83 & 0.17 \\
\hline
\end{tabular}

\section{References}

1. Woodhouse, J. Briefing: Standards in Asset Management: PAS 55 to ISO 55000. Infrastruct. Asset Manag. 2014, 1, 57-59. [CrossRef]

2. ISO. Asset Management-Management Systems_Requirements; ISO 55001:2014; International Organization for Standardization (ISO): Geneva, Switzerland, 2014. 
3. Hastings, N.A.J. Physical Asset Management: With an Introduction to ISO55000; Springer: Berlin/Heidelberg, Germany, 2015; ISBN 978-3-319-14777-2.

4. IAM (Institute of Asset Management). The IAM Competences Framework Part 1: Asset Management Competence Requirements Framework; Institute of Asset Management: London, UK, 2014.

5. Chattopadhyay, G. Asset Management Journey for Realising Value from Assets. In Handbook of Advanced Performability Engineering; Misra, K.B., Ed.; Springer International Publishing: Cham, Germany, 2021; pp. 429-450. ISBN 978-3-030-55732-4.

6. ISO. Asset Management-Overview, Principles and Terminology; ISO 55000:2014; International Organization for Standardization (ISO): Geneva, Switzerland, 2014.

7. Trindade, M.; Almeida, N.; Finger, M.; Ferreira, D. Design and Development of a Value-Based Decision Making Process for Asset Intensive Organizations. In Asset Intelligence through Integration and Interoperability and Contemporary Vibration Engineering Technologies; Mathew, J., Lim, C.W., Ma, L., Sands, D., Cholette, M.E., Borghesani, P., Eds.; Springer International Publishing: Cham, Germany, 2019; pp. 605-623.

8. Pacaiova, H.; Nagyova, A. Risk Based Thinking-New Approach for Modern Enterprises' Management. In Proceedings of the Advances in Human Factors, Business Management and Society, Orlando, FL, USA, 21-25 July 2018; Springer: Cham, Germany, 2018; pp. 524-536.

9. Maletič, D.; Maletič, M.; Al-Najjar, B.; Gomišček, B. An Analysis of Physical Asset Management Core Practices and Their Influence on Operational Performance. Sustainability 2020, 12, 9097. [CrossRef]

10. Komljenovic, D.; Gaha, M.; Abdul-Nour, G.; Langheit, C.; Bourgeois, M. Risks of Extreme and Rare Events in Asset Management. Saf. Sci. 2016, 88, 129-145. [CrossRef]

11. Pačaiová, H.; Sinay, J.; Nagyová, A. Development of GRAM-A Risk Measurement Tool Using Risk Based Thinking Principles. Measurement 2017, 100, 288-296. [CrossRef]

12. Almeida, N.M.; Sousa, V.; Dias, L.A.; Branco, F. Engineering Risk Management in Performance-Based Building Environments. J. Civil Eng. Manag. 2015, 21, 218-230. [CrossRef]

13. Maletič, D.; Pačaiová, H.; Nagyová, A.; Maletič, M. The Link Between Asset Risk Management and Maintenance Performance: A Study of Industrial Manufacturing Companies. Qual. Innov. Prosper. 2020, 24, 50-69. [CrossRef]

14. Lima, E.S.; Lorena, A.L.F.; de Costa, A.P.C.S. Structuring the Asset Management Based on ISO 55001 and ISO $31000:$ Where to Start? In Proceedings of the 2018 IEEE International Conference on Systems, Man, and Cybernetics (SMC), Miyazaki, Japan, 7-10 October 2018; pp. 3094-3099.

15. Komljenovic, D.; Abdul-Nour, G.; Boudreau, J.-F. Risk-Informed Decision-Making in Asset Management as a Complex Adaptive System of Systems. Int. J. Strateg. Eng. Asset Manag. 2019, 3, 198-238. [CrossRef]

16. ISO. Risk Management_Guidelines; ISO 31000:2018; International Organization for Standardization (ISO): Geneva, Switzerland, 2018.

17. Parida, A.; Stenström, C. Asset Performance Evaluation: A Recipe for Success or Failure. In Proceedings of the 29th International Congress on Condition Monitoring and Diagnostic Engineering Management, Xi'An, China, 20-26 August 2016.

18. Parida, A.; Stenström, C. Dynamic Asset Performance Management. In Handbook of Advanced Performability Engineering; Misra, K.B., Ed.; Springer International Publishing: Cham, Germany, 2021; pp. 403-428. ISBN 978-3-030-55732-4.

19. Gavrikova, E.; Volkova, I.; Burda, Y. Strategic Aspects of Asset Management: An Overview of Current Research. Sustainability 2020, 12, 5955. [CrossRef]

20. Lima, E.S.; McMahon, P.; Costa, A.P.C.S. Establishing the Relationship between Asset Management and Business Performance. Int. J. Prod. Econ. 2020, 107937. [CrossRef]

21. IAM (Institute of Asset Management). The IAM Competences Framework Part 2: Guidance on Using the 2012 Asset Management Competence Requirements Framework; Institute of Asset Management: London, UK, 2014.

22. Asset Management. Part 1: Specification for the Optimised Management of Physical Assets; BSI PAS 55-1; British Standards Institution: London, UK, 2008.

23. Certification Competencies-Asset Management Council. Available online: https://www.amcouncil.com.au/certification/ certification_competency_tree.aspx (accessed on 8 December 2020).

24. The Canadian Network of Asset Managers Association (CNAM). Asset Management Competency Framezork for Canadian Communities; The Canadian Network of Asset Managers Association: Toronto, ON, Canada, 2020.

25. GFMAM. GFMAM Competency Specification for an ISO 55001: Asset Management System Auditor/Assesor; Kelowna, BC, Canada, 2014; Available online: https://theiam.org/media/1342/isbn978_0_9871799_5_1_gfmam_iso55001_auditor_assessor_specification_ edition_1_v2_english.pdf (accessed on 6 January 2021).

26. ISO. Maintenance-Qualification of Maintenance Personnel; EN 15628:2014; CEN EN—European Committee for Standardization: Geneva, Switzerland, 2014.

27. Varajão, J.; Cruz-Cunha, M.M. Using AHP and the IPMA Competence Baseline in the Project Managers Selection Process. Int. J. Prod. Res. 2013, 51, 3342-3354. [CrossRef]

28. Robertson, I.T.; Smith, M. Personnel Selection. J. Occup. Organ. Psychol. 2001, 74, 441-472. [CrossRef]

29. Hodkiewicz, M.R.; Pascual, R. Education in Engineering Asset Management-Current Trends and Challenges. In Proceedings of the International Physical Asset Management Conference, Tehran, Iran, 28-31 January 2006. 
30. Lemerande, T. Managing Competence in Naval Asset Management: Professionalising Defence's Cadre of Asset Managers for Ships and Submarines. In Engineering Assets and Public Infrastructures in the Age of Digitalization; Liyanage, J.P., Amadi-Echendu, J., Mathew, J., Eds.; Springer International Publishing: Cham, Germany, 2020; pp. 475-482.

31. Saaty, T.L. The Analytic Hierarchy Proces—Planning, Priority Setting, Resource Allocation; McGraw-Hill: New York, NY, USA, 1980.

32. Saaty, T.L. Decision Making with the Analytic Hierarchy Process. Int. J. of Serv. Sci. 2008, 1, 83-98. [CrossRef]

33. Smith, J.T.; Tighe, S.L. Analytic Hierarchy Process as a Tool for Infrastructure Management. Transp. Res. Rec. 2006, 1974, 2-9. [CrossRef]

34. Zyoud, S.H.; Shaheen, H.; Samhan, S.; Rabi, A.; Al-Wadi, F.; Fuchs-Hanusch, D. Utilizing Analytic Hierarchy Process (AHP) for Decision Making in Water Loss Management of Intermittent Water Supply Systems. J. Water Sanit. Hyg. Dev. 2016, 6, 534-546. [CrossRef]

35. Goepel, K.D. Implementing the Analytic Hierarchy Process as a Standard Method for Multi-Criteria Decision Making in Corporate Enterprises-A New AHP Excel Template with Multiple Inputs. In Proceedings of the International Symposium on the Analytic Hierarchy Process, Kuala Lumpur, Malaysia, 23-26 June 2013. [CrossRef]

36. Saaty, T.L. What Is the Analytic Hierarchy Process? In Mathematical Models for Decision Support; Mitra, G., Greenberg, H.J., Lootsma, F.A., Rijkaert, M.J., Zimmermann, H.J., Eds.; Springer: Berlin/Heidelberg, Germany, 1988; pp. $109-121$.

37. Talib, F.; Rahman, Z.; Qureshi, M.N. Prioritising the Practices of Total Quality Management: An Analytic Hierarchy Process Analysis for the Service Industries. Total Qual. Manag. Bus. Excell. 2011, 22, 1331-1351. [CrossRef]

38. GFMAM. The Asset Management Landscape, 2nd ed.; Kelowna, BC, Canada, 2014; Available online: https://www.gfmam.org/ sites/default/files/2019-05/GFMAMLandscape_SecondEdition_English.pdf (accessed on 6 January 2021).

39. UK Roads Liaison Group. Asset Management (AM) Competence Framework; UK Roads Liaison Group: London, UK, 2019.

40. El-Akruti, K.; Dwight, R.; Zhang, T. The Strategic Role of Engineering Asset Management. Int. J. Prod. Econ. 2013, 146, 227-239. [CrossRef]

41. Xerri, M.J.; Nelson, S.A.; Brunetto, Y.; Reid, S.R.M. NPM and Change Management in Asset Management Organisations. J. Organ. Chang. Manag. 2015, 28, 641-655. [CrossRef]

42. Kregel, I.; Ogonek, N.; Matthies, B. Competency Profiles for Lean Professionals-An International Perspective. Int. J. Product. Perform. Manag. 2019, 68, 423-446. [CrossRef]

43. Vladeanu, G.J.; Matthews, J.C. Consequence-of-Failure Model for Risk-Based Asset Management of Wastewater Pipes Using AHP. J. Pipeline Syst. Eng. Pract. 2019, 10, 04019005. [CrossRef]

44. Ratnayake, R.M.C. Sustainable Performance of Industrial Assets: The Role of PAS 55-1\&2 and Human Factors. Int. J. Sustain. Eng. 2013, 6, 198-211. [CrossRef]

45. Adriaensen, A.; Decré, W.; Pintelon, L. Can Complexity-Thinking Methods Contribute to Improving Occupational Safety in Industry 4.0? A Review of Safety Analysis Methods and Their Concepts. Safety 2019, 5, 65. [CrossRef]

46. Turisova, R.; Sinay, J.; Pacaiova, H.; Kotianova, Z.; Glatz, J. Application of the EFQM Model to Assess the Readiness and Sustainability of the Implementation of I4.0 in Slovakian Companies. Sustainability 2020, 12, 5591. [CrossRef]

47. Salvendy, G. Handbook of Human Factors and Ergonomics, 4th ed.; John Wiley \& Sons: Hoboken, NJ, USA, 2012.

48. Polenghi, A.; Roda, I.; Macchi, M.; Trucco, P. Risk Sources Affecting the Asset Management Decision-Making Process in Manufacturing: A Systematic Review of the Literature, Proceedings of the Advances in Production Management Systems. Production Management for the Factory of the Future, Austin, TX, USA, 1-5 September 2019; Ameri, F., Stecke, K.E., von Cieminski, G., Kiritsis, D., Eds.; Springer International Publishing: Cham, Switzerland, 2019; pp. 274-282. 